\title{
The Impact of Ideology on Translation of News Stories
}

\author{
Javad Azodi \\ Department of English, Tabriz Branch, Islamic Azad University, Tabriz, Iran \\ Department of English, East Azarbaijan Science and Research Branch, Islamic Azad University, Tabriz, Iran \\ E-mail: javad.azodii@gmail.com \\ Bahloul Salmani (Corresponding Author) \\ Department of English, Tabriz Branch, Islamic Azad University, Tabriz, Iran \\ E-mail: bsalmani@iaut.ac.ir
}

Doi:10.7575/aiac.alls.v.6n.1p.163

URL: http://dx.doi.org/10.7575/aiac.alls.v.6n.1p.163
Received: 25/09/2014

Accepted: 10/12/2014

\begin{abstract}
Translation has always undergone the impact of various metalinguistic factors which impose their impact during the process of translation and rendering its final linguistic product. News stories or better to say political discourses are among those linguistic materials that more than other textual materials undergo the impact of factors such as ideology. Not being aware of such discursive practices leads the so-called translator to suffice to linguistic substitutions without observing imbedded intentions. For the purpose of this study through a qualitative type of research and based on critical discourse analysis (CDA) approach for textual analysis and following van Dijk's concept of ideology (2002) in translation this study aimed to scrutinize the impact of ideology on Persian translations of different pieces of news stories in English in 2012. The corpus consisted of some pieces of English news stories in worldwide news agencies (namely, Reuters, Washington Post, New York Post, and Forbes) about Iran's nuclear program. Results of the study showed that ideology was the very important stimulus which can control and direct the purpose of the news stories being translated from English to Persian and revealed its impact in a desired way as news stories for target audience.
\end{abstract}

Keywords: Ideology, Translation, Critical Discourse Analysis, News Translation

\section{Introduction}

Translation as a form of cross-cultural communication and the meeting point of different civilizations can undergo different ideological manipulations in order to serve the favor of dominant authority and or power. Translation in bilingual and multilingual contexts plays a vital role in gaining, establishing and maintaining political and or expressing ideology. Understanding the reproduction of news stories through translation can be studied as function of both textual and contextual (cognitive) properties of the communication process by which different factors show up to influence the final outcome deliberately. Translation is a powerful means of producing knowledge and transferring information through a process which is under the influence of diverse factors namely to say: ideology, power, politics, etc. (van Dijk, 1988, p. 2). In target-language, translation might in fact be used to fulfill a communicative purpose or function that is quite distinct from the original function of source text. The added value, so to speak, will be in close relation to the new context, the purposes that translators and other agents (who use the translation or for whom it is done) pursue and their overall political goals. Thus, particular textual features of translated texts have to be related to the wider social, political, cultural context of their production and reception, and the various choices that were made by the translator can be interpreted (at least tentatively) in terms of the wider goals and strategies pursued by agents in the cultural and political field, and in terms of the norms and constraints operating in these fields (Fairclough, 2008, p.68).Consequently the present study is a type of qualitative-interpretive research applying critical discourse analysis approach to unfold the impact of ideology and power on the translation of news stories with focus on a number of political samples of English news stories from different pieces of news and news networks and their corresponding translation in Fars News online news agency.The fact that translators are constrained in many ways; by the very language of source text; by the expectations of dominant authority; by socio-cultural context in which they are working and the underlying ideologies, reveals that translation is a provincial way to encounter the strangeness of languages. It also becomes a form of control, particularly if there are purposeful directions behind any communicative act or responsibility. Being aware that translating is not merely passing from one text to another, or transferring words from one container to another rather transport and clash between two cultures, the importance of ideology comes into light. The analysis shows that the manipulation of translation and deviations from source text (here English) are neither arbitrary nor constrained by the translator's incompetence, but largely motivated by existing ideology through media discourses. 


\section{Literature Review}

\subsection{A Prospective on Ideology}

The notion of ideology was first introduced by French Philosopher Destutt de Tracy at the end of 18th century. For him ideology is nothing more than a general "science of ideas" (the study of how we think, speak and argue...), something what today would be called psychology or even cognitive science. As it could be inferred from Tracy's writings, ideologies have something to do with systems of ideas, and especially with the social, political or religious ideas shared by a social group or movement. Communism as well as anti-communism, socialism and liberalism and etc. are examples of wide-spread ideologies- which may be more or less positive or negative depending on our point of view or group membership. Group members who share such ideologies stand for a number of very general ideas that are at the basis of their more specific beliefs about the world, guide their interpretation of events, and monitor their social practices (Van Dijk, 2002, p. 6).

Fairclough (2010) believes that ideology, is first, a relation between (and therefore texts) social relations of power and domination. It is one modality of power (another is physical force). And ideology is first, a matter of representation. He points out that discourses may be called "ideological" where social analysis plausibly shows a relation between their meanings (ways of representing) and social relations of power. Supposing discourses to be ideological, their dialectical semiotic and non-semiotic internalization in ways of acting and ways of being (enhancement, inculcation) as well as their materialization in the physical word is also an internalization of ideology. Therefore, the term ideology, in other words, would seem to make reference not only to belie systems, but to the question of power. Perhaps it may be claimed that ideology has to do with legitimizing the power of a dominant social group or class (Eagleton, 1991, p.5).

In modern debate on ideology, two main argumentative strands or tendencies can be distinguished. One position argues that ideologies as false theories about reality can be overcome and replaced by scientific theories and/or scientifically founded agency; another (dialectical) position assumes that ideology is an unavoidable moment of all thinking and acting. So the word ideology, one might say, is a text, woven of a whole tissue of different conceptual strands. To indicate this variety of meaning Eagleton lists 16 categories which reveal differences in meaning and consideration namely; the process of production of meanings, signs and values in social life; a body of ideas characteristic of a particular social group or class; ideas which help to legitimize a dominant political power; systematically distorted communication and etc. (Wodak, 2007, p.1).Because of existing narrow approaches towards the ambiguous notion of ideology, many theorists have preferred to use the concept of discourse instead of ideology during the last two decades after the collapse of the Soviet Union. They have perceived discourse theory as enabling them a more complex analysis compared to the Marxist notion of ideology as a simplistic and negative process whereby individuals were duped into using conceptual systems which were not in their own interests (Althusser, 1984, p. 58).

\subsection{Ideology and Translation}

Translation is of course, a rewriting of an original text. All rewritings, whatever their intention, reflect a certain ideology and a poetics and as such manipulates literature to function in a given society in a given way (Bassenet\&Lefever, 1992, p. vii). Hodge, Kress and Jones (1979) point out the significance of language in studying the concept of ideology;

\footnotetext{
'Ideologies are sets of ideas involved in ordering of experience, making sense of the world. Such order and sense is partial and particular. The systems of ideas which constitute ideologies are expressed through language. Language supplies the models and categories of thought, and in part people's experience of the world is through language"' (p.81).

Considering translation as a communicative act in which the present socio-cultural context and ideological trends of the translator's environment are revealed, translators not only transfer the ideological aspects of the original text, but also they may leave some ideological traces of their own. Therefore, in the process of translating any given text both the semantic meaning and ideologically invested meanings are proposed by translators. The operation of ideology can be seen in terms of ways of constructing texts which constantly and cumulatively impose assumptions upon the interpreters and text producers, typically without either being aware of it (Fairclough, 1989, p.83).In other words, the target text includes socio-cultural and ideologically embedded reflections of translator, as well as his/her attitudes and mental images. Existing socio-cultural constraints in any culture introduce the occurrence of inevitable divergences, alterations and discrepancies which result in manifestation of different ideological consequences.
}

Tymoczko argues that ideological aspects of translation are inextricable from the "place of enunciation" of the translator, and that this place is not simply geographical but also temporal and ideological. The ideology of a translation is not located in the translated text alone, but also in the voice and positioning of the translator, and our understanding of this positioning has been influenced by the tendency to speak of translation itself as an in between space (Baker, 2012, p.213).Schaffner (2003) indicates;

'Ideological aspects through translation can be determined within a text itself, both at lexical level (reflected, for example, in the deliberate choice or avoidance of a specific word) and the grammatical level (for example, use of passive structures to avoid an expression of agency). Ideological aspects can be more or less obvious in texts, depending on the topic of a text, its genre and communicative purposes" (p.23). 


\subsection{Critical Discourse Analysis}

For critical discourse analysis, language is not powerful on its own - it gains power by the use powerful people make of it. This explains why critical discourse analysis often chooses the perspective of those who suffer, and critically analyzes the language use of those in power, who are responsible for the existence of inequalities and who also have the means and the opportunity to improve conditions. In agreement with its Critical Theory predecessors, critical discourse analysis emphasizes the need for interdisciplinary work in order to gain a proper understanding of how language functions in constituting and transmitting knowledge, in organizing social institutions or in exercising power (Wodak\& Meyer, 2001, 10).Fairclough (1995) argues that CDA is discourse analysis which aims to systematically explore often opaque relationships of causality and determination between (a) discursive practices, events and texts, and (b) wider social and cultural structures, relations, and processes; to investigate how such practices, events and texts arise out of and are ideologically shaped by relations of power and struggles over power; and to explore how the opacity of these relationships between discourse and society are itself a factor securing power and hegemony (pp. 132-3).

Wodak (1996, pp. 17-20) proposes some general principles for critical discourse analysis as follow:

- Critical discourse analysis is concerned with social problems. It is not concerned with language or language use per se, but with the linguistic character of social and cultural processes, and structures.

- Power-relations have to do with discourse, and critical discourse analysis studies both power in discourse and power over discourse.

- Society and culture are dialectically related to discourse: society and culture are shaped by discourse and at the same time to constitute discourse. Every single instance of language use reproduces or transforms society and culture, including power relations.

- Language use may be ideological. To determine this it is necessary to analyze texts to investigate their interpretation, reception and social effects.

- Discourses are historical and can only be understood in relation to their context.

- Discourse analysis is interpretive and explanatory. Critical discourse analysis implies a systematic methodology and a relationship between the text and its social conditions, ideologies and power relations.

\subsection{News Translation}

Van Dijk (1988, pp. 1-2) points out that news reports whether in the press or on TV, constitute a particular type of discourse. The influence of the social sciences in the study of mass communication has led to focus on the economic, political, social, or psychological aspects of news processing. Such orientation provides important insights into the conditions of news production and into the uses or effects of mass media reporting. Another orientation is to address the very core of the process of mass media communication, viz the mediated discourses themselves. Media discourses in general, and news reports in particular, should also be accounted for in their own right, e.g., as particular types of language use or text and as specific kinds of socio cultural practices.According to GarcíaSuárez (2005) one of the main concerns of the news translator is the problem of objectivity rather than faithfulness to the source text, a feature that is particularly relevant and central in the translation of agency news, to which he refers:

"In the case of a news translator, and specifically of a translator who works in a news agency, what is characteristic is that faithfulness to the original text is subordinated to faithfulness to the narrated facts, which on some occasions and whenever there exists a clear justification allows for the introduction of alterations of meaning, which are intolerable to a translator specialized in other fields; that is to say, it obliges the translator to combine his translating task with the task of a journalistic editor'" (pp. 175-76).

The kind of intervention demanded by news translation on the original text modifies the traditional role of the translator in relation to both the author and the source text. Translators' historical, cultural and socioeconomic dependence - their subordinate position in the cultural field - has been theorized in terms of their ingrained subservience "to the client, to the public, to the author, to the text, to language itself' (Simeoni, 1998, pp. 11-12).Richardson (2007) discusses that the theory and method of news analysis must be an interpretive, constructive and contextual approach. It means that critical discourse analysts: offer interpretations of the meanings of text rather than just quantifying textual features and deriving meaning from this; situate what is written or said in the context in which it occurs, rather than just summarizing patterns or regularities in texts; and argue that textual meaning is constructed through an interaction between producer, text and consumer rather than simply being read off the page by all readers in exactly the same way. Therefore we need to be familiar with what actually quantitative content analysis of newspapers is. The relationships between purposes, content and effects are, only inferred or suggested in content analysis, since it only studies ' the manifest content of communication' not any social or contextual factors outside of , or subsequent to, the text itself. So this results in different readings of meaning and therefore potentially different coding (pp.15-17).

\section{Corpus and Method}

This research is done based on qualitative-interpretive method with a critical discourse analysis approach to analyze translation of news stories with independent variable i.e. ideology in the process of translation and dependent variable i.e. the imposed impact on translation itself. The research is briefly conducted at textual level (word/sentence level) and 
consequently at discourse level. Since it is concerned with non-statistical methods of inquiry and analysis of translation, hence the results are mostly qualitative and interpretive and the need for readers' own interpretation is considered.The researcher in order to study the impact of power and ideology on the process and product of translation focused on news stories of different English news agencies and their corresponding translations in Fars news (an Iranian web based news agency) in 2014. Most of the news stories refer to news about ongoing nuclear talks between Iran and the world powers .The researcher believes selected samples out of the mentioned corpus for this study are of ideological importance and reveal applied discursive practices in their presentation. This study benefits from a comparative style in which the original text is read and compared with its translation. The researcher read different news stories in source language (English) and compared them with corresponding translations in target language (Persian) considering the ideological load on rendering translations.

\section{Data Analysis}

The main goal of this section is to analyze samples regarding the notion of ideology whether in the process or product of translation. This section deals with the analysis of selected samples out of the corpus of the study, which are pieces of news in English (ST) from different international news agencies and their corresponding translations in Persian (TT) in Fars News; a web based news agency. Analysis is based on qualitative-interpretive type benefiting from critical discourse analysis approach and following van Dijk's concept of ideology (2002) in translation studies. First, the news stories in source language (English) were studied and compared with their corresponding translations in target language (Persian) in order to find manipulated or twisted parts. Second, those manipulated parts of news stories were written separately along with their corresponding translation and the altered textual areas were underlined in order to clarify the point. Then, a brief table is presented showing the parts in question, and related translations and back translations for each sample to clarify more the specific problem which is going to be dealt with in following discussion. Finally, the following section (4.1) represents thoroughly the discussion of samples both at textual and discourse level.

\section{Sample 1:}

Piece of news in this sample is about United States' biased view on so-called MKO group and its translation regarding Iran's point of view on the said group.

FOXNEWS (ST) writes:

Joseph Lieberman on Tuesday called for Iran resistance fighters to be brought to the United States...

Source: www.foxnews.com $(2014 / 07 / 13)$

FARSNEWS (TT) translates:

$$
\text { زوزف ليبرمن روز سه شنبه خو استار انتقال اعضاي كرو هك تروريستي منافقين به ايالات متحده شد ... }
$$

Source: www.farsnews.com $(2014 / 07 / 15)$

Back-translation of TT:

Joseph Lieberman on Tuesday called for Members of MKO terrorist group to be brought to the United States ...

\section{Sample 2:}

Piece of news in this sample is about Iran's nuclear program and activities.

NEWYORK POST (ST) writes:

Today regarding Iran' nuclear program the demand is for slow-motion bomb making.

Source: www.nypost.com $(2014 / 07 / 07)$

FARSNEWS (TT) translates:

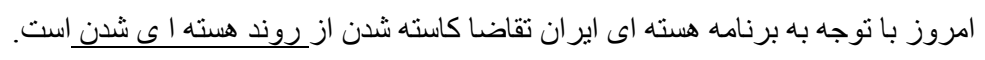

Source: $\underline{\text { www.farsnews.com }}(2014 / 07 / 08)$

Back-translation of TT:

Today regarding Iran' nuclear program the demand is for slow-motion in nuclear progress.

\section{Sample 3:}

Piece of news in this sample is about Iran's nuclear program and activities. 
Iran should prove that its nuclear ambitions are entirely peaceful.

Source: www.reuters.com $(2014 / 07 / 06)$

FARSNEWS (TT) translates:

ايران بايد ثابت كند كه برنامه هسته ابي آن كاملا صلح آميز است.

Source: www.farsnews.com (2014/07/08)

Back-translation of TT:

Iran should prove that its nuclear program is entirely peaceful.

\section{Sample 4:}

Piece of news in this sample is about United States' biased view on so-called MKO group and its translation regarding Iran's point of view on the said group.

FOX NEWS (ST) writes:

Nearly 3,000 members of the National Council of Resistance to Iran are stationed at camp Liberty.

Source: www.foxnews.com $(2014 / 07 / 13)$

FARSNEWS (TT) translates:

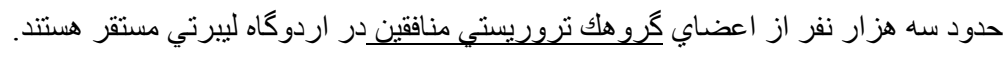

Source: www.farsnews.com $(2014 / 07 / 15)$

Back-translation of TT:

Nearly 3,000 members of the MKO terrorist group are stationed at camp Liberty.

\section{Sample 5:}

Piece of news in this sample is about United States' biased view on so-called MKO group and its translation regarding Iran's point of view on the said group.

FOXNEWS (ST) writes:

Lieberman said the resistance fighters at camp liberty are freedom fighters ...

Source: www.foxnews.com $(2014 / 07 / 13)$

FARSNEWS (TT) translates:

$$
\text { لييرمن اظهار داشت: اين افر اد در اردوكاه لييرتي مبارزان آزادي هستتد .... }
$$

Source: www.farsnews.com $(2014 / 07 / 15)$

Back-translation of TT:

These people at camp liberty are freedom fighters ...

\section{Sample 6:}

Piece of news in this sample is about sanctions imposed on Iran and United States' plans towards applying further embargos on Iran.

REUTERS (ST) writes:

Republication lawmakers introduced legislation that gives lawmakers the chance to reject the deal with Iran and impose sanctions.

Source: www.reuters.com $(2014 / 07 / 10)$

FARSNEWS (TT) translates:

جمعى از نمايندكان جمهورى خواه لايحه اى را ار ايه كردند كه بر اساس آن اعضاى كنكرى مى تو انند درباره بذيرش تو افق با ايران تصميم كيرى كنتن.

Source: www.farsnews.com (2014/07/10) 
A group of republication lawmakers introduced legislation that congress memberscan decide on accepting the deal with Iran.

\section{Sample 7:}

Piece of news in this sample is about is about United States' false understanding of Iran's nuclear program.

NEWYORK TIMES (ST) writes:

The highly unusual move by the Justice Department raises questions about the connections between the American government and the group UANI, seeking to prevent Iran from obtaining nuclear weapon.

Source: www.nytimes.com $(2014 / 08 / 04)$

FARS NEWS (TT) translates:

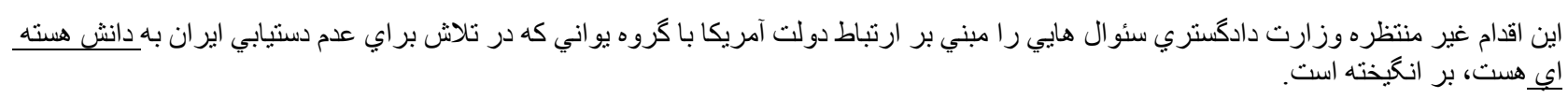
Source: www.farsnews.com $(2014 / 08 / 05)$

Back-translation of TT:

The unexpected action by the Justice Department raises questions about the connections between the American government and the group UANI, seeking to prevent Iran from obtaining nuclear knowledge.

\section{Sample 8:}

Piece of news in this sample is about the United States intervention in Iraq's affair and possibility of cooperation between the United States and Iran.

WORLDNEWS (ST) writes:

Joint Chief of staff Chairman General Martin Dempsey recently claimed it is "not impossible" that the U.S will begin coordinating its military operations in Iraq with Iran.

Source: www.worldnews.com $(2014 / 08 / 03)$

FARSNEWS (TT) translates:

$$
\text { رييس ستاد مشترك امريكا زنر ال دميسي مدعي شد كه احتمال همكاري امريكا با ايران در امور عر اق غير ممكن نيست. }
$$

Source: $\underline{w w w . f a r s n e w s . c o m}(2014 / 08 / 03)$

Back-translation of TT:

Joint Chief of staff Chairman General Martin Dempsey recently claimed it is "not impossible" that the U.S will cooperate with Iran concerning Iraq's affairs.

\section{Sample 9:}

Piece of news in this sample is about Iraqi government and their struggle against ISIS fighters.

TIME MAGAZINE (ST) writes:

The ISIS spokesman warned that his fighters would take revenge against al-Maleki's regime, which is dominated by $\underline{\text { Shi'ites. }}$

Source: www.time.com $(2014 / 07 / 28)$

FARSNEWS (TT) translates:

سخنكوي دولت اسلامي عر اق و شام بيان داشت كه جنحجويان آن در بي انتقام ازنوري مالكي هستند كه از سوي بسياري از شيعيان جهان حمايت مي

Source: $\underline{w w w . f a r s n e w s . c o m}(2014 / 07 / 30)$

Back-translation of TT:

The ISIS spokesman declared that his fighters would take revenge against al-Maleki, who is supported by the majority of Shi'ites in the world. 


\section{Sample 10:}

Piece of news in this sample is about Iran's nuclear program and related activities.

THE TRUMPET (ST) writes:

The West's main goal is to prevent Iran from acquiring nuclear weapon.

Source: www.thetrumpet.com $(2014 / 07 / 22)$

FARSNEWS (TT) translates:

هدف عمده غرب عدم دسترسي اير ان به نو ان هسته ابي است.

Source: www.farsnews.com $(2014 / 07 / 22)$

Back-translation of TT:

The West's main goal is to prevent Iran from acquiring nuclear power.

Table1. Scope of different ideological manipulations done by translator, in translation of news from English (ST) into Persian (TT).

\begin{tabular}{|c|c|c|}
\hline Part of news in ST in question & Represented translation in TT & Back-translation of TT \\
\hline Iran resistance fighters & اعضاي كرو هك تروريستي منافقين & Members of MKO terrorist group \\
\hline bomb making & روند هسته ایى شدن & nuclear progress \\
\hline nuclear ambitions & برنامه هسته اي & nuclear program \\
\hline $\begin{array}{l}\text { the National Council of Resistance to } \\
\text { Iran }\end{array}$ & كرو هك تروريستي منافقين & the $\mathrm{MKO}$ terrorist group \\
\hline the resistance fighters & اين افراد & These people \\
\hline $\begin{array}{l}\text { Gives lawmakers the chance to reject } \\
\text { the deal with Iran and impose } \\
\text { sanctions. }\end{array}$ & 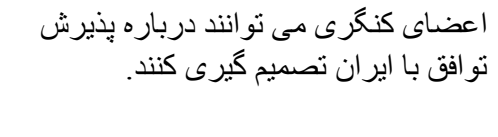 & $\begin{array}{l}\text { Congress members can decide on } \\
\text { accepting the deal with Iran. }\end{array}$ \\
\hline nuclear weapon & دانش هسته اي & nuclear knowledge \\
\hline military operations in Iraq & امور عراق & Iraq's affairs \\
\hline $\begin{array}{l}\text { Al-Maleki's regime, which is } \\
\text { dominated by Shi'ites. }\end{array}$ & جهان حمايت مي شود كه از سوي بسياري از شيعيان & $\begin{array}{l}\text { Al-Maleki, who is supported by the } \\
\text { majority of Shi'ites in the world. }\end{array}$ \\
\hline nuclear weapon & توان هسته اي & nuclear power \\
\hline
\end{tabular}

\subsection{Discussion of Research Samples at Textual and Discourse Levels (Results and Discussions)}

As it can be seen, in samples number one, four and five regarding the representation of the group called 'Iranian

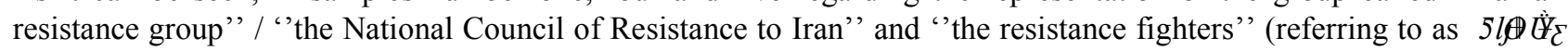

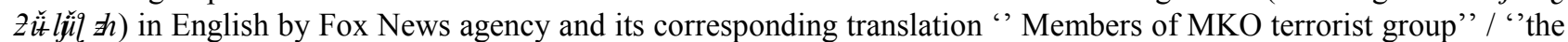
MKO terrorist group'” and or “'these people” (اين افر اد/اعضاي/كرو هك تروريستي منافقين) in Persian by Fars News agency, it is obvious that the translator has intentionally directed the translation to express the harsh negative view of its patrons (here Iranian government) towards the said group and excludes the group from Iranian community. In this way the ideological difference in considering the said group whether a legitimate institution by Fox News (better to say American officials) or illegitimate one by Fars News (better to say Iranian government and community) results in a translation which cannot be regarded as mistranslation, but a predefined and constant concept that declares opposition towards the same people by Iranian translator. Since the so-called group from its establishment in 1965 has caused lots of dramatic and sever problems for Iranian community and after the glorious Islamic Revolution of Iran arranged numerous terrorist attacks to the body of revolution, its noble leaders during the period of revolution and imposed war, and even after it, and as long as they are continuing their hostility towards Iranian government and community it is not surprising that Iran does not share the same point of view with the United States . This is the way that Van Dijk indicates that members of a social group (here Iranian government and community) marginalize, exclude, or problematize the members of others group(s) in infinitely subtle way (2002, p. 31).

Obviously Persian translation for "'bomb making", (ساخت بمب) in sample two i.e. "nuclear progress" (روند هسته ایى), and

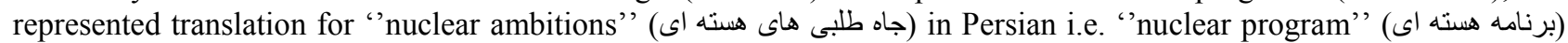
in sample three, and also the Persian translation i.e." nuclear knowledge" (دانش هسته ایى) substituted for "nuclear weapon" (سلاح هسته اى) in sample seven are not the exact corresponding translation for the source text. World powers believe that Iranian nuclear program is going to reach the required level for producing a nuclear weapon/ bomb and Iranian government introduces excess ambitions and demands. For this they claim that enriched uranium stock in 
different nuclear facilities of Iranian nuclear facilities is at a very high level of enrichment which makes the Iranian government to be capable of producing a nuclear bomb. Therefore, in any occasion they try to express the possibility of bomb making capability of Iran. However Iran has already oxidized a great bulk of its highly enriched uranium stocks to ensure the world that its nuclear program and related activities are entirely peaceful. Therefore, it will not be surprising that the translator works in the favor of his patrons (here Iranian government) and translates the shared dominant ideology. This is where Van Dijk believes that such concept of dominant ideology refers to ideologies employed by dominant group(s) in the reproduction or legitimization of their dominance as well as the language use for obtaining predefined purposes"' (2002, p. 45).

In addition, by a close scrutiny it is clear that the translations rendered for " Al-Maleki's regime, which is dominated by Shi'ites" (دولت مالكى كه تحت سيطره شيعيان است) i.e. " Al-Maleki, who is supported by the majority of Shi'ites in the

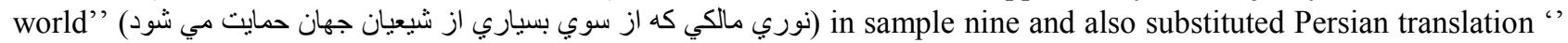

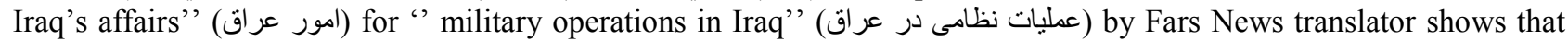
the source text has been manipulated intentionally to signal presupposed ideological trends which Iranian government believes to be true and appropriate regarding the political and regional situation of Iraq. Since Iranian government is the only Shi'ite dominated government in the world and especially in the region of the Middle East it is not surprising that the Iranian news agency tends to render the concepts which are in accordance with its government's ideology and religious trends. Also Iranian government tries to cooperate with Iraq's government in its entire domestic and or foreign affairs and the outlines of governing the country. Hence in this way it can transfer its Islamic ideologies in policy making and controlling the state of Iraq appropriately. This is a good example of what Van Dijk regards as the fact that people having a common ground would share the same system of beliefs and produce a great bulk of knowledge which socio-culturally manifests shared ideas" (2002, pp. 6 \& 13).

Regarding the impact of ideology on translation final product there has been a good body of related researches. Zhang (2012) in 'Translation Manipulated by Ideology and Poetics"' studies the possible manipulation in translation and draws upon to elaborate on how ideology and poetics manipulate poetry translation, including the choice of theme and translation strategy in the case of 'The Jade Mountain'. Keshavarz and Alimadadi (2011) in " Manipulation of Ideology in Translation of Political Texts" study, attempted to probe into the manipulation of ideologies in translations of political texts benefiting from a Critical Discourse Analysis approach. They concluded that translators make use of certain grammatical and lexical strategies for the sake of ideological ploy, i.e. the basic strategy of positive selfpresentation and negative other-presentation. Hirv (2011) devotes his thesis " Ideology in Translation/Transfer' to study the news from a specific linguistic and cultural environment to an international level regarding the online coverage of the controversial "Bronze Night" in the articles of the Estonian public broadcaster and two foreign public broadcasters with the aim to find out whether they construct the events from ideologically different viewpoints. He concluded that there always exist ideological differences in translation, understood as cultural transfer, in news while considering the particularities of media discourse.

The present study aimed at drawing attention upon the impact of ideology on translation of news stories. As for van Dijk (2002, p. 31) " many of our social practices are imbued by ideologies. As soon as people act as members of a social group (here Iranian community) they bring to bear their ideologies in their actions and reactions. In this way they marginalize, exclude, or problematize the members of others group(s) in infinitely subtle way" as it was seen in samples one, four and five. Hence we are to be precise in interpreting the product of translation and take into account the political and socio-cultural context in which the translator works. Meanwhile different ideological trends which surround the translators working environment are of great importance in considering the purpose of certain directions applied at the face of process and product of translation of news from English into Persian as it was seen in samples two, three, seven and ten. The Persian translator's ideology and also the ongoing ideological trends of Iranian community are effective factors which direct the process of translation of news stories in English into Persian. It should also be noted that the translator renders the final product of materials under translation (here English news stories) in the way that represents the most dominant ideology of Iranian community on specific issues and topics which have been developed as predefined ideological structures according to Iranian government's outlines and policies. This means that opposition towards presupposed notions and concepts is not permitted if the translator wants to have an acceptable translation. Since ideologies indirectly control social practices in general, and discourse in particular, the obvious further social function of ideologies is facilitating joint action, interaction and cooperation of in-group and out-group members. In other words, ideologies are the beginning and end, the source and the goal of group practices. Hence, such concept of dominant ideology refers to ideologies employed by dominant group(s) in the reproduction or legitimization of their dominance as well as the language use for obtaining predefined purposes (ibid, p.45) as it can be understood scrutinizing samples six, eight, nine and ten.

\section{Conclusion}

This study investigated the impact of ideology on the translation of news stories from English (ST) into Persian (TT) through identifying the possible manipulations imposed by the translators working for the favor of the dominant ideology or power in the context of Iranian community. Analysis was made on the selected samples out of the corpus of the study according to qualitative-interpretive type of research with a critical discourse analysis approach. The analysis benefited from van Dijk's (2002) points of view on existing ideological trends in translation process in order to clarify possible manipulations imposed by the translator of news stories serving for an Iranian news agency. As mentioned before, the act of translation in its very initial stage and the involved process all in all affect the final product of translation. Now considering translation as a productive process which does not absolutely represent a faithful image of 
the source text (here English news) and being aware of the fact that translated material will not be rendered as an unbiased linguistic material, the importance of intervene done by power relations stands at the spotlight of attention. The surrounding context in which the translator translates even usually outlines the selection of linguistic materials to be translated let alone how the translation must be presented, i.e. what to include or exclude.

\section{References}

Baker, M. (2012).Critical readings in translation studies (ed.), Routledge publications.

Bassenet, S. \&Lefever, A (1992). Translation; Ideology.In Translation, Rewriting and the manipulation of the literary frame (1992)/ Routledge publications, London \& New York.

Eagleton, T. (1991) Ideology an Introduction. London \& New York: CC Verso 1991.

Fairclough, I. (2008). CRITICAL DISCOURSE ANALYSIS AND TRANSLATION STUDIES: TRANSLATION, RECONTEXTUALIZATION, IDEOLOGY

Fairclough, N. (1989). Language and power (discourse, common sense and ideology). C Longman Group UK Limited 1989.

Fairclough, N. (2010); critical discourse analysis; the critical study of language/ second edition(C Pearson education limited.

GarcíaSuárez, P. (2005). Noticias de agencia: algunosproblemasplanteados en la traducciónespañol-árabe. In Bassenett, S.andBielsa, E. (2009) Translation in Global News. Published by: Routledge.

Richardson, J. (2007) Analyzing Newspapers -An Approach from Critical Discourse Analysis. Published by; PALGRAVE MACMILLAN.

Schaffner, C. (2003). Third ways and new centers; ideological unity or difference in M.Calzada-Pere (Ed.).Apropos of ideology (pp. 23-42), Manchester; St. Jerome.

Simeoni, D. (1998). The Pivotal Status of the Translator's Habitus. Target, 10(1), 1-39- In Bassenett, S. And Bielsa, E. (2009) Translation in Global News. Published by: Routledge.

Van Dijk, A (2002) political discourse and ideology; In In Clara UbaldinaLorda\& MontserratRibas (Eds.), Anàlisi del discurspolític. (pp. 15-34). Barcelona: UniversitatPompeuFabra. IULA, 2002.

Van Dijk, T. (1988) NEWS ANALYSIS (CASE STUDIES OF INTERNATIONAL AND NATIONAL NEWS IN THE PRESS) chapter 1: The Analysis of News as Discourse, pp. 1-2. LAWRENCE ERLBAUM ASSOCIATES, PUBLISHERS.

Wodak, R. (1996) Disorders of Discourse. London: Longman- In E. Richardson, J. (2007) Analyzing Newspapers -An Approach from Critical Discourse Analysis. Published by; PALGRAVE MACMILLAN Theory and Methodology. London: Sage.

Wodak, R., and M. Meyer.(2001). Methods of Critical Discourse Analysis. Great Britain: SAGE Publications.

www.foxnews.com/www.farsnews.com

www.nypost.com /www.washingtonpost.com 